\title{
Tetrodotoxin Poisoning Due to Pufferfish and Gastropods, and Their Intoxication Mechanism
}

\author{
Tamao Noguchi, ${ }^{1}$ Kazue Onuki, ${ }^{1}$ and Osamu Arakawa ${ }^{2}$ \\ ${ }^{1}$ Faculty of Healthcare, Tokyo Healthcare University, Setagaya, Tokyo 154-8568, Japan \\ ${ }^{2}$ Graduate School of Fisheries Science and Environmental Studies, Nagasaki University, Nagasaki 852-8521, Japan
}

Correspondence should be addressed to Kazue Onuki, k-onuki@thcu.ac.jp

Received 19 July 2011; Accepted 7 September 2011

Academic Editor: D. Drobne

Copyright (C) 2011 Tamao Noguchi et al. This is an open access article distributed under the Creative Commons Attribution License, which permits unrestricted use, distribution, and reproduction in any medium, provided the original work is properly cited.

Marine pufferfish generally contain a large amount of tetrodotoxin (TTX) in their skin and viscera, and have caused many incidences of food poisoning, especially in Japan. Edible species and body tissues of pufferfish, as well as their allowable fishing areas, are therefore clearly stipulated in Japan, but still 2 to 3 people die every year due to pufferfish poisoning. TTX is originally produced by marine bacteria, and pufferfish are intoxicated through the food chain that starts with the bacteria. Pufferfish become nontoxic when fed TTX-free diets in a closed environment in which there is no possible invasion of TTX-bearing organisms. On the other hand, TTX poisoning due to marine snails has recently spread through Japan, China, Taiwan, and Europe. In addition, TTX poisoning of dogs due to the ingestion of sea slugs was recently reported in New Zealand. TTX in these gastropods also seems to be exogenous; carnivorous large snails are intoxicated by eating toxic starfish, and necrophagous small-to-medium snails, the viscera of dead pufferfish after spawning. Close attention must be paid to the geographic expansion and/or diversification of TTX-bearing organisms, and to the sudden occurrence of other forms of TTX poisoning due to their ingestion.

\section{Introduction}

In Japan, tetrodotoxin (TTX) is the most common natural marine toxin to cause food poisoning, and it poses a serious hazard to public health. This toxin $\left(\mathrm{C}_{11} \mathrm{H}_{17} \mathrm{~N}_{3} \mathrm{O}_{8}\right.$; Figure 1) is a potent neurotoxin with a molecular weight of 319 , whose various derivatives have been separated from pufferfish, newts, frogs, and other TTX-bearing organisms [1]. When ingested by humans, TTX acts to block the sodium channels in the nerve cells and skeletal muscles [2], and to thereby block excitatory conduction, resulting in the occurrence of typical symptoms and signs (Table 1 ) and even death in severe cases [3]. The lethal potency is 5000 to $6000 \mathrm{MU} / \mathrm{mg}$ (1 MU (mouse unit) is defined as the amount of toxin required to kill a 20 -gram male mouse within $30 \mathrm{~min}$ after intraperitoneal administration), and the minimum lethal dose for humans is estimated to be approximately 10,000 MU ( $\approx 2 \mathrm{mg}$ ).

Since 1964 [4], the distribution of TTX has spread to animals other than pufferfish, including newts, gobies, frogs, octopuses, gastropods, starfish, crabs, flatworms, and ribbon worms (Table 2) [5, 6]. Pufferfish are thought to accumulate TTX through several steps of the food chain, starting from TTX production by marine bacteria (Figure 2) [6, 7]. TTX poisoning due to marine gastropods occurs not only in Japan [5], but also in China [3], Taiwan [3], Europe [8], and New Zeeland [9], suggesting further diversification of TTX-bearing organisms and therefore geographic expansion of TTX poisoning. In the present paper, we review TTX poisoning cases due to the ingestion of pufferfish and gastropods, and discuss the TTX intoxication mechanism of these organisms in an effort to contribute to the development of an effective means of protecting humans against TTX poisoning.

\section{TTX Poisoning due to Pufferfish}

Marine pufferfish of the family Tetraodontidae generally contain a large amount of TTX in their skin and viscera, 


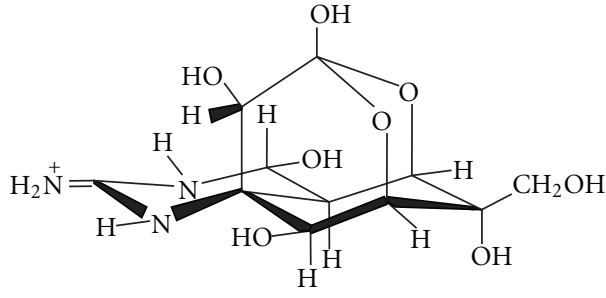

Hemilactal form

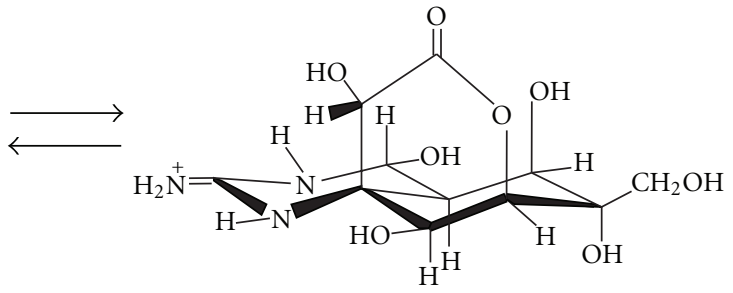

10,7-Lactone form

FIgure 1: Chemical structure of TTX.

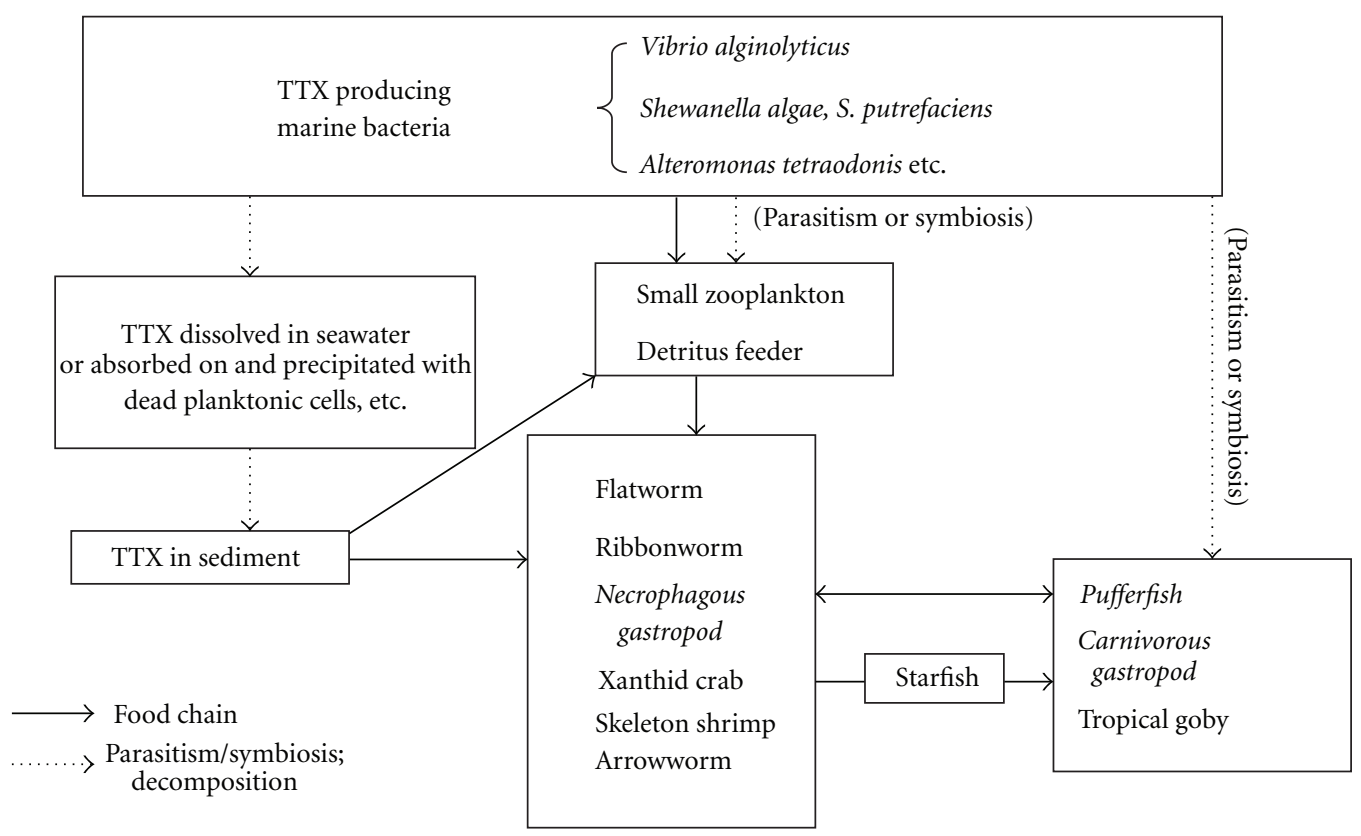

FIgURE 2: Proposed mechanism of TTX intoxication in marine animals.

especially the liver and ovary [6]. Accordingly, edible species and their body tissues, and the allowable pufferfish fishing areas have been clearly stipulated in Japan since 1983, but still several tens of people are poisoned by pufferfish annually, and 2 to 3 people die as a result of pufferfish poisoning (Table 3). The incidence in specializing restaurants is rare, and most cases of poisoning result when people with little knowledge of pufferfish toxicity cook a pufferfish that they caught or received from someone else and mistakenly eating strongly toxic parts such as liver and ovary. Some pufferfish fans dare to ingest the liver, believing that the toxin can be eliminated by their own special detoxification methods.

In October 2008, a 69-year-old male died at a hospital in Isahaya, Nagasaki Prefecture [10]. He stated that he cooked a "usubahagi" (a sort of thread-sail filefish "kawahagi") that he caught by himself and ate its raw meat (sashimi) after dipping in a mixture of the liver and soy sauce. Approximately 30 minutes after ingestion, he felt numbness in his limbs, and 30 minutes later, he vomited and became comatose before being transported by an ambulance to the hospital. The doctor confirmed his death approximately 4 hours after ingestion, with an initial diagnosis of "ciguatera due to the ingestion of "kawahagi" liver, the possibility of TTX is not denied". Thereafter, it was determined that the patient cooked a "kinfugu" (local name of pufferfish) with the "usubahagi," but the liver was missing among the leftovers. We investigated the leftovers, and revealed that the "usubahagi" was nontoxic, but the "kinfugu" was actually a highly toxic species, "komonfugu" Takifugu poecilonotus, and $600 \mathrm{MU} / \mathrm{g}$ of TTX was detected in the skin. Furthermore, $0.7 \mathrm{MU} / \mathrm{mL}$, $2 \mathrm{MU} / \mathrm{mL}$, and $45 \mathrm{MU} / \mathrm{g}$ of TTX was detected in the blood, urine, and vomit of the patient, respectively, leading to the conclusion that this was a case of TTX intoxication due to the mistaken ingestion of T. poecilonotus liver.

Recently, the nonedible pufferfish Lagocephalus lunaris, which usually inhabits tropical or subtropical waters, has been frequently mixed up with edible species in Japanese coastal waters, posing a serious food hygiene problem. This pufferfish, which bears a very similar appearance to the almost nontoxic species $L$. wheeleri, also possesses high levels of TTX in their muscles $[6,11]$, caused 5 poisoning incidents in 11 patients due to mistaken ingestion in Kyushu 
TABLE 1: Symptoms of TTX poisoning.

\begin{tabular}{|c|c|}
\hline Degree & Characteristic symptoms \\
\hline First & $\begin{array}{l}\text { Neuromuscular symptoms (paresthesia of lips, tongue, and pharynx; taste disturbance; dizziness; headache; } \\
\text { diaphoresis; pupillary constriction); gastrointestinal symptoms (salivation, hypersalivation, nausea, vomiting, } \\
\text { hyperemesis, hematenesis, hypermotility, diarrhea, abdominal pain) }\end{array}$ \\
\hline Second & $\begin{array}{l}\text { Additional neuromuscular symptoms (advanced general paresthesia; paralysis of phalanges and extremities; } \\
\text { pupillary dilatation, reflex changes) }\end{array}$ \\
\hline Third & $\begin{array}{l}\text { Increased neuromuscular symptoms (dysarthria; dysphagia, aphagia; lethargy; incoordination, ataxia; floating } \\
\text { sensation; cranial nerve palsies; muscular fasciculations); cardiovascular/pulmonary symptoms (hypotension } \\
\text { or hypertension; vasomotor blockade; cardiac arrhythmias including sinus bradycardia, asystole, tachycardia, } \\
\text { and atrioventricular node conduction abnormalities; cyanosis; pallor; dyspnea); dermatologic symptoms } \\
\text { (exfoliative dermatitis, betechiae, blistering) }\end{array}$ \\
\hline Fourth & $\begin{array}{l}\text { Respiratory failure, impaired mental faculties, extreme hypotension, seizures, loss of deep tendon and spinal } \\
\text { reflexes }\end{array}$ \\
\hline
\end{tabular}

TABLE 2: Distribution of TTX in animals other than pufferfish.

\begin{tabular}{|c|c|c|c|c|}
\hline Animals & & & Toxic parts & Maximal toxicity \\
\hline Platyhelminthes & Turbellaria, Flatworms & Planocera spp. & Whole body & $>1000 \mathrm{MU} / \mathrm{g}$ \\
\hline Nemertinea & Ribbonworms & $\begin{array}{l}\text { Lineus fuscoviridis } \\
\text { Tubulanus punctatus } \\
\text { Cephalothrix linearis }\end{array}$ & $\begin{array}{l}\text { Whole body } \\
\text { Whole body } \\
\text { Whole body }\end{array}$ & $\begin{array}{l}>1000 \mathrm{MU} / \mathrm{g} \\
100-1000 \mathrm{MU} / \mathrm{g} \\
>1000 \mathrm{MU} / \mathrm{g}\end{array}$ \\
\hline \multirow[t]{2}{*}{ Mollusca } & Gastropoda & $\begin{array}{c}\text { Charonia sauliae } \\
\text { Charonia lampas lampas } \\
\text { Babylonia japonica } \\
\text { Tutufa lissostoma } \\
\text { Zeuxis siquijorensis } \\
\text { Niotha clathrata } \\
\text { Niotha lineata } \\
\text { Cymatium echo } \\
\text { Pugilina ternotoma } \\
\text { Pleurobranchaea maculata }\end{array}$ & $\begin{array}{l}\text { Digestive gland } \\
\text { Digestive gland } \\
\text { Digestive gland } \\
\text { Digestive gland } \\
\text { Whole body } \\
\text { Whole body } \\
\text { Whole body } \\
\text { Digestive gland } \\
\text { Digestive gland } \\
\text { skin }\end{array}$ & $\begin{array}{c}>1000 \mathrm{MU} / g \\
10-100 \mathrm{MU} / \mathrm{g} \\
100-1000 \mathrm{MU} / \mathrm{g} \\
>1000 \mathrm{MU} / \mathrm{g} \\
>1000 \mathrm{MU} / \mathrm{g} \\
>1000 \mathrm{MU} / \mathrm{g} \\
10-100 \mathrm{MU} / \mathrm{g} \\
10-100 \mathrm{MU} / \mathrm{g}\end{array}$ \\
\hline & Cephalopoda & Hapalochlaena maculosa & $\begin{array}{c}\text { Posterior salivary } \\
\text { gland (adult), Whole } \\
\text { body (semi-adult) }\end{array}$ & >1000 MU/g \\
\hline Annelida & Polychaeta & Pseudopolamilla occelata & Whole body & $10-100 \mathrm{MU} / \mathrm{g}$ \\
\hline \multirow[t]{2}{*}{ Arthropoda } & Xanthidae crabs & $\begin{array}{c}\text { Atergatis floridus } \\
\text { Zosimus aeneus }\end{array}$ & $\begin{array}{l}\text { Whole body } \\
\text { Whole body }\end{array}$ & $\begin{array}{l}10-100 \mathrm{MU} / \mathrm{g} \\
10-100 \mathrm{MU} / \mathrm{g}\end{array}$ \\
\hline & Horseshoe crab & Carcinoscorpius rotundicauda & Egg & $10-100 \mathrm{MU} / \mathrm{g}$ \\
\hline Chaetognatha & Arrowworms & $\begin{array}{c}\text { Parasagitta spp. } \\
\text { Flaccisagitta spp. }\end{array}$ & $\begin{array}{l}\text { Head } \\
\text { Head }\end{array}$ & $\begin{array}{l}\text { detected } \\
\text { detected }\end{array}$ \\
\hline Echinodermata & Starfish & Astropecten spp. & Whole body & $100-1000 \mathrm{MU} / \mathrm{g}$ \\
\hline \multirow[t]{6}{*}{ Vertebrata } & Pisces, Goby, Amphibia & Yongeichthys criniger & Skin, viscera, gonad & $100-1000 \mathrm{MU} / \mathrm{g}$ \\
\hline & & Tarica spp. & $\begin{array}{l}\text { Skin, egg, ovary, } \\
\text { muscle, blood }\end{array}$ & $100-1000 \mathrm{MU} / \mathrm{g}$ \\
\hline & & Notophthalmus spp. & Skin, egg, ovary & $10-100 \mathrm{MU} / \mathrm{g}$ \\
\hline & Newts & Cynopsis spp. & $\begin{array}{l}\text { Skin, egg, ovary, } \\
\text { muscle, blood }\end{array}$ & 10-100 MU/g \\
\hline & & Triturus spp. & $\begin{array}{l}\text { Skin, egg, ovary, } \\
\text { muscle, blood }\end{array}$ & detected \\
\hline & Frogs & $\begin{array}{l}\text { Atelopus spp. } \\
\text { Colostethus sp. } \\
\text { Polypedates sp. } \\
\text { Brachycephalus spp. }\end{array}$ & $\begin{array}{c}\text { Skin } \\
\text { Skin } \\
\text { Skin } \\
\text { Skin, liver }\end{array}$ & $\begin{array}{c}>1000 \mathrm{MU} / \mathrm{g} \\
100-1000 \mathrm{MU} / \mathrm{g} \\
100-1000 \mathrm{MU} / \mathrm{g} \\
100-1000 \mathrm{MU} / \mathrm{g}\end{array}$ \\
\hline
\end{tabular}


Table 3: Pufferfish poisoning incidents in Japan.

\begin{tabular}{|c|c|c|c|c|}
\hline Year & $\begin{array}{c}\text { Number of } \\
\text { incidents }\end{array}$ & Number of patients & Number of deaths & $\begin{array}{c}\text { Mortality } \\
(\%)\end{array}$ \\
\hline 1965 & 106 & 152 & 88 & 57.9 \\
\hline 1970 & 46 & 73 & 33 & 45.2 \\
\hline 1975 & 52 & 75 & 30 & 40.0 \\
\hline 1980 & 46 & 90 & 15 & 16.7 \\
\hline 1985 & 30 & 41 & 9 & 22.0 \\
\hline 1990 & 33 & 55 & 1 & 1.8 \\
\hline 1995 & 30 & 42 & 2 & 4.8 \\
\hline 1996 & 21 & 34 & 3 & 8.8 \\
\hline 1997 & 28 & 44 & 6 & 13.6 \\
\hline 1998 & 27 & 39 & 4 & 10.3 \\
\hline 1999 & 20 & 34 & 2 & 5.9 \\
\hline 2000 & 29 & 40 & 0 & 0.0 \\
\hline 2001 & 31 & 52 & 3 & 5.8 \\
\hline 2002 & 37 & 56 & 6 & 10.7 \\
\hline 2003 & 28 & 35 & 3 & 8.6 \\
\hline 2004 & 44 & 61 & 2 & 3.3 \\
\hline 2005 & 40 & 49 & 2 & 4.1 \\
\hline 2006 & 26 & 33 & 1 & 3.0 \\
\hline 2007 & 29 & 44 & 3 & 6.8 \\
\hline 2008 & 40 & 56 & 3 & 5.4 \\
\hline 2009 & 24 & 50 & 0 & 0.0 \\
\hline 2010 & 23 & 29 & 0 & 0.0 \\
\hline
\end{tabular}

and Shikoku Islands during 2008-2009. Though not as frequent as in Japan, many food poisoning cases due to ingestion of wild pufferfish have also occurred in China and Taiwan $[3,6]$.

\section{TTX Poisoning due to Gastropods}

TTX-bearing gastropods and the food poisoning incidents due to their ingestion are summarized in Tables 4 and 5, and Figure 3.

3.1. Large Marine Snails. Although the trumpet shell Charonia sauliae is not usually sold on the market, it is sometimes eaten locally in Japan. In December 1979, a man in Shimizu, Shizuoka Prefecture, Japan, ingested the digestive gland of $C$. sauliae and was seriously poisoned. He showed paralysis of his lips and mouth, and respiration failure, which are the typical symptoms and signs of pufferfish poisoning. TTX was detected for the first time in a marine snail, that is, the leftovers of $C$. sauliae, and the causative agent was therefore concluded to be TTX [12]. Similar poisonings occurred in 1 patient in the Wakayama Prefecture in December 1982, and in 2 patients in the Miyazaki Prefecture in January 1987.

In C. sauliae, TTX localizes in the digestive gland, and other organs, including the muscle, are nearly nontoxic [12]. The digestive gland toxicity of $C$. sauliae collected from Shimizu Bay in 1981 ranged from 77 to $350 \mathrm{MU} / \mathrm{g}$. A subsequent toxicity survey based on a total of 1406 digestive glands of C. sauliae from 7 prefectures indicated that the frequency of toxic specimens in each prefecture ranged from $19 \%$ to $87 \%$. TTX or its derivative been also detected in closely related species, such as the frog shell Tutufa lissostoma [13] and the European trumpet shell Charonia lampas lampus [8], the latter of which caused TTX poisoning in Spain in 2007.

3.2. Medium Marine Snails. The ivory shell Babylonia japonica is usually ingested as a side dish with sake. In June 1957, 5 persons were poisoned due to ingestion of the shellfish in Teradomari, Niigata Prefecture, and 3 of them died [14]. The causative substance was estimated to be TTX based on the facts that the symptoms and signs of the victims were similar to those of the pufferfish poisoning, and that TTX was later detected in B. Japonica collected from Kawajiri Bay, Fukui Prefecture in May 1980 [15].

In April 2004, a food poisoning incident resulting from the ingestion of the necrophagous marine snail Nassarius (Alectricon) glans occurred in Tungsa Island located in the South China Sea, Taiwan. Five patients were involved, and there were 2 deaths. The causative agent was identified as TTX by instrumental analyses $[16,17]$. In a toxicity survey of $20 \mathrm{~N}$. glans specimens collected from the same sea area, high toxicity was observed not only in the digestive gland, but also in the muscle (average of 538 and $1167 \mathrm{MU} / \mathrm{g}$, resp.).

TTX poisonings due to $N$. glans have also occurred in Japan recently [10]. In July 2007 in Nagasaki, Nagasaki 
TABLE 4: TTX-bearing gastropods and food poisoning cases due to them in Japan.

\begin{tabular}{|c|c|c|c|c|c|}
\hline Name of gastropod & Poisoning Year & Place & Number of patient & Number of death & Predatory habit \\
\hline Ivory shell, Babylonia japonica & 1957, Jun. & Niigata & 5 & 3 & Necrophagous \\
\hline \multirow{3}{*}{ Trumpet shell, Charonia sauliae } & 1979, Dec. & Shizuoka & 1 & 0 & Carnivorous \\
\hline & 1982, Dec. & Wakayama & 1 & 0 & Carnivorous \\
\hline & 1987, Jan. & Miyazaki & 2 & 0 & Carnivorous \\
\hline \multirow{2}{*}{ "Kinshibai," Alectricon glans } & 2007, Jul. & Nagasaki & 1 & 0 & Necrophagous \\
\hline & 2008, Jul. & Kumamoto & 1 & 0 & Necrophagous \\
\hline Frog shell, Tutufa lissostoma & & Shizuoka & & & Carnivorous \\
\hline $\begin{array}{l}\text { "Hanamushirogai," Zeuxis } \\
\text { siquijorensis }\end{array}$ & & Shizuoka & & & Necrophagous \\
\hline "Araregai," Niotha clathrata & & Shizuoka & & & Necrophagous \\
\hline Total & & & 11 & 3 & \\
\hline
\end{tabular}

TABLE 5: TTX-bearing gastropods and food poisoning cases due to them in other countries.

\begin{tabular}{|c|c|c|c|c|c|}
\hline \multicolumn{6}{|l|}{ Taiwan and China } \\
\hline Name of gastropod & Poisoning Year & Place & Number of patient & Number of death & Predatory habit \\
\hline Zeuxis samiplicutus & 1977-2001, Jun. & Zhoushan, China & 310 & 16 & Necrophagous \\
\hline $\begin{array}{l}\text { Niotha clathrata, } \\
\text { Zeuxis scalaris }\end{array}$ & 1994, May & Pingtung, Taiwan & 26 & 0 & Necrophagous \\
\hline Z. sufflatus, N. clathrata & 2001, Apr. & Taipei, Taiwan & 5 & 0 & Necrophagous \\
\hline \multirow{2}{*}{ Z. siquijorensis } & 2002 & Fujian, China & $>20$ & $>3$ & Necrophagous \\
\hline & 2004 & China & 55 & 1 & \\
\hline \multirow{2}{*}{ Zeuxis sp. and/or Niotha sp. } & 2002, Jul. & Tsingtao, China & 3 & 0 & Necrophagous \\
\hline & 2002-up to date & Fujian to Tsingtao, China & - & - & Necrophagous \\
\hline Total & & & $>419$ & $>20$ & \\
\hline \multicolumn{6}{|l|}{ New Zealand } \\
\hline $\begin{array}{l}\text { Sea slug, Pleurobranchaea } \\
\text { maculata }\end{array}$ & 2009, Jul. & Auckland & & 14 (dogs) & $\begin{array}{l}\text { Herbivorous } \\
\text { Carnivorous }\end{array}$ \\
\hline
\end{tabular}

Prefecture, a 60-year-old female developed a feverish feeling in the limbs, abdominal pain, and an active flush and edema in the face 15 minutes after ingesting the shellfish and was administered intravenous fluids at a clinic near her home. Thereafter, her condition worsened, and she developed dyspnea, whole-body paralysis, and mydriasis; she was finally transported to an emergency hospital. The patient required an artificial respirator for the first 3 days, but recovered enough to take breakfast on the 4 th day. She unexpectedly relapsed after lunch, however, and developed respiratory arrest and was placed on the respirator again. She gradually recovered and was discharged from the hospital 3 weeks later.

Immediately after the incident, we investigated the leftover gastropods and detected a maximum of $4290 \mathrm{MU} / \mathrm{g}$ of TTX in the cooked muscles and digestive glands of N. glans. Moreover, during subsequent investigations, an extremely high concentration of TTX and a putative derivative of TTX, that is, a maximum of $10,200 \mathrm{MU} / \mathrm{g}(15,100 \mathrm{MU} /$ individual) in the viscera and $2370 \mathrm{MU} / \mathrm{g}$ (9860 MU/individual) in the muscle, were detected in $N$. glans specimens collected from the same sea area as the ingested snail [18]. In this case, the once-recovered symptoms recurred after the patient began eating again. Although the reason is not clear, the recurrence might have been due to the digestion of a highly toxic, previously undigested tissue fragment of $N$. glans and absorption due to the resumption of meals, again exposing her respiratory center to a high concentration of TTX. In July 2008, another poisoning incident due to N. glans occurred in Amakusa, Kumamoto Prefecture.

3.3. Small Marine Snails. In association with the occurrence of TTX poisoning by C. sauriae in Shizuoka Prefecture in 1979, TTX screening was performed in several species of small marine snails in Japan. Zeuxis siquijorensis [19] and Niotha clathrata [20] were found to possess TTX or a TTXlike substance. There have been, however, no poisoning cases in Japan, as Japanese people do not typically feed on these species. On the other hand, inhabitants along the coast of the East China Sea in China and Taiwan have a long history of eating small marine snails, and Zeuxis spp. N. clathrata, and Natica spp. are generally sold at the supermarket or fish markets in these areas. From 1977 to 2004, more than 419 people were poisoned by ingesting these snails, and 


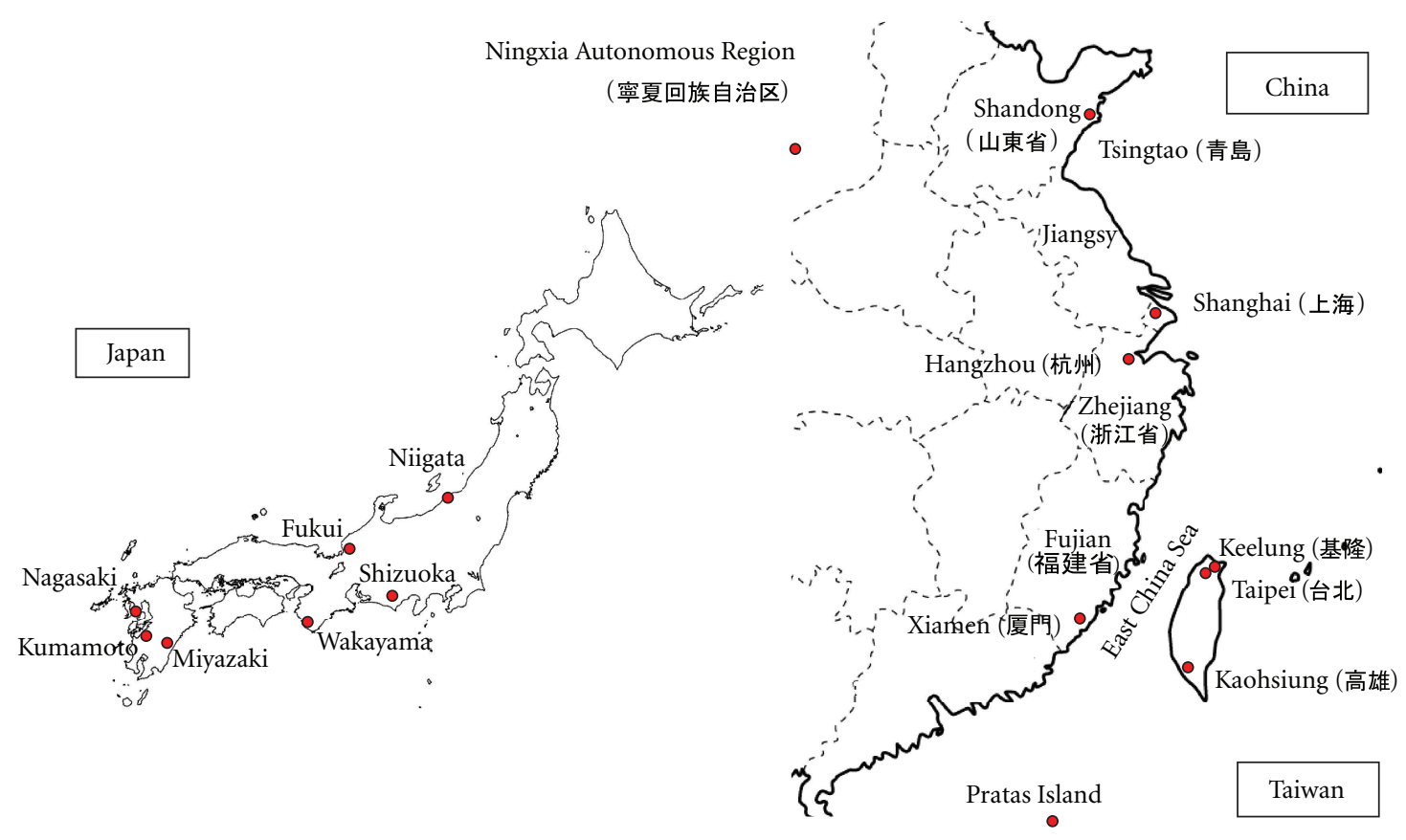

FIgUre 3: Maps showing the locations where TTX poisoning due to marine snails occurred in Japan, China, and Taiwan.

over 19 people died in Zhoushan, Fujian, and the Ninxia Hui Automous Region in China [3, 21-23]. Furthermore, poisoning cases have spread along the coasts from Fujian to Tsuingtao. In 1994 and 2001, similar poisonings occurred in the southern and northern parts of Taiwan, respectively, and the main causative substance was identified as TTX [23-25].

3.4. Sea Slugs. From July to November 2009, 15 dogs were suddenly poisoned at the beaches adjacent to Hauraki Gulf, Auckland, New Zealand, all exhibiting similar symptoms, and 5 of them died. McNabb et al. [9] detected a very high level of TTX in the grey side-gilled sea slug Pleurobranchaea maculate found in tide pools near the beach and claimed that the dogs were poisoned with TTX by contact with the sea slugs. TTX was found in the eggs and larvae and distributed over the whole body with increasing concentrations toward the outer tissues in the adult sea slugs.

\section{TTX Intoxication Mechanism of Pufferfish}

Marked individual and regional variations are observed in pufferfish toxicity. In addition, the facts that the TTX of $C$. sauliae and B. Japonica comes from the food chain as described below and that several shell fragments of $Z$. siquijorensis are detected in the digestive tract of the toxic pufferfish Takifugu pardalis suggest that TTX contained by pufferfish is exogenous via the food chain [6, 7]. Moreover, many studies of TTX have revealed that (1) TTX is distributed over various organisms other than pufferfish, (2) marine bacteria primarily produce TTX (Table 6), (3)
TABLE 6: Primary TTX producers.

\begin{tabular}{lc}
\hline Marine bacteria & Source \\
\hline Vibrio alginolyticus & From starfish \\
Vibrio VIII & From crab \\
Shewanella algae & From Jania sp. \\
Alteromonas tetraodonis & \\
S. putrefaciens & From pufferfish \\
Other marine bacteria & \\
\hline
\end{tabular}

pufferfish become nontoxic when they are fed TTX-free diets in a closed environment in which there has been no invasion of TTX-bearing organisms, (4) such nontoxic pufferfish efficiently accumulate TTX when TTX is orally administered, and (5) pufferfish are equipped with high resistance to TTX, supporting the exogenous intoxication theory-a hypothesis that TTX is originally produced by marine bacteria, and pufferfish accumulate TTX through the food chain that starts with the bacteria $[6,7]$.

To test (3), we investigated the toxicity of more than 8700 individual pufferfish that had been reared in an environment in which the invasion of TTX-bearers was prevented and were provided nontoxic diets in netcages in the sea, or in tanks with an open or closed circulation system on land, and confirmed that all the livers remained nontoxic (Table 7) $[6,25]$. Production of nontoxic pufferfish can reduce the risk of food poisoning from eating toxic pufferfish and reduce the mortality rate. Moreover, this method might 
TABLE 7: Toxicity of cultured pufferfish liver (1982-2009).

\begin{tabular}{lcccc}
\hline Culture & Year of collection & Age & Number of collection & Toxicity (MU/g) \\
\hline Sea & $1981-2003$ & $1-3$ & 4258 & $<2-<10$ \\
Land & & & 4504 & $<2-<8$ \\
$\quad$ open system & $2001-2009$ & $1-2$ & 4173 & \\
\multicolumn{1}{c}{ closed system } & $2008-$ & $1-2$ & 331 & \\
\hline Total & & 8762 & \\
\hline
\end{tabular}

also contribute to maintain the Japanese food culture by reviving pufferfish liver dishes as a safe traditional food, which, although eaten previously, has been prohibited as a food since the regulation of 1983 in Japan. The transfer, accumulation, and elimination mechanisms of TTX taken up into the pufferfish body via food organisms remain unclear. We recently found that TTX administered intramuscularly to nontoxic cultured specimens of the pufferfish Takifugu rubripes was transferred first to the liver and then to the skin via the blood [26]. Matsumoto/Nagashima et al. demonstrated that, unlike general nontoxic fish, the liver tissue of T. rubripes is equipped with a specific TTX-uptake mechanism [27-29], and using a pharmacokinetic model showed that TTX introduced into the pufferfish body is rapidly taken up into the liver via the blood $[30,31]$. These findings indicate that marine pufferfish are endowed with a mechanism by which they transport TTX specifically and actively. TTX-binding proteins have been isolated from the blood plasma of marine pufferfish, and may be involved in the transportation mechanism [32,33].

In wild pufferfish, the liver and ovary usually have strong toxicity, whereas the muscle and testis are weakly toxic or nontoxic [6]. In addition, the toxicity varies with the season, usually reaching the highest level during the spawning season (March to June in Japan), indicating sexual differences in pufferfish toxicity and that maturation may affect toxin kinetics in the pufferfish body. Recently, we investigated seasonal changes in tissue toxicity and the amount and forms of TTX in the blood plasma using wild specimens of the pufferfish T. poecilonotus and demonstrated that maturation greatly affects the intertissue transfer and/or accumulation of TTX via the bloodstream [34].

\section{TTX Intoxication Mechanism of Gastropods}

5.1. Large Marine Snails. The trumpet shell C. sauliae is a carnivorous marine snail, and fragments of the starfish Astropecten polyacanthus were detected in the digestive tract of the specimens collected from Shimizu Bay in association with the food poisoning in 1979. The starfish were toxic, and the toxic molecule was identified as TTX [35]. The closely related species A. scoparius [36] and A. latespinosus [37] also had TTX. Moreover, an experiment in which nontoxic $C$. sauliae were fed toxic starfish demonstrated that the TTX of C. sauliae is derived from these starfish, namely, their food source $[35,38]$. The starfish of genus Astropecten are also carnivorous, and their toxin is also estimated to come from their food.
5.2. Medium Marine Snails. The ivory shell B. japonica is necrophagous and feeds on the muscles and viscera of dead fish. In the Hokuriku and Joetsu districts along the Japan Sea where Sakajiri Bay is located, and TTX intoxication of $B$. japonica was recognized in 1980 [15], fishermen are familiar with the feeding habits of $B$. japonica and catch them using the viscera of dead toxic pufferfish Takifugu niphobles as bait. We performed a similar experiment with C. sauliae and observed that $B$. japonica preferentially ate dead pufferfish viscera, thereby accumulating TTX. It is presumed that the B. japonica that caused poisoning in Teradomari of the Joetsu district were intoxicated with TTX by a similar mechanism.

Although the TTX intoxication mechanisms of $N$. glans in Tsungsa Island as well as Nagasaki and Kumamoto Prefectures are unclear, the necrophagous characteristics of the snail suggest that dead pufferfish viscera are one of the origins of TTX. The toxicity of the Nagasaki/Kumamoto specimens of N. glans collected from September to January was highest in September, and gradually decreased thereafter (Figure 4) $[10,18]$. There are no data on the other months, but both poisoning incidents in Nagasaki and Kumamoto occurred in July, indicating that the $N$. glans had already accumulated a high concentration of TTX that month. In Japan, T. niphobles comes en masse to the seashore to spawn their eggs in June, and die shortly thereafter. The spawning season of T. niphobles almost corresponds to the intoxication season of $N$. glans, indicating a possibility that $N$. glans is intoxicated by feeding on the mass of dead $T$. niphobles at the sea bottom.

5.3. Small Marine Snails. The occurrence of food poisoning cases in China and Taiwan is concentrated from spring to early summer (Table 5 ), somewhat earlier than that of the Nagasaki/Kumamoto incidents. On the other hand, the season during which toxic pufferfish approach the seacoast in a group to spawn is earlier in China and Taiwan than in Japan, as the latitude of the area where the poisonings occur is lower than that of Japan proper (Figure 3). Therefore, the season when poisonings occur appears to correspond to the spawning season of toxic pufferfish. The small marine snails that have caused food poisonings in China and Taiwan are all necrophagous, having the same feeding habit as $B$. japonica and N. glans, and seem to be intoxicated by the same mechanism; they accumulate TTX by feeding on the viscera of toxic pufferfish that died after spawning.

In this context, TTX has been found to act as an attractant to toxic marine snails. In our experiment using 8 toxic and 2 nontoxic snail species to investigate the attracting 


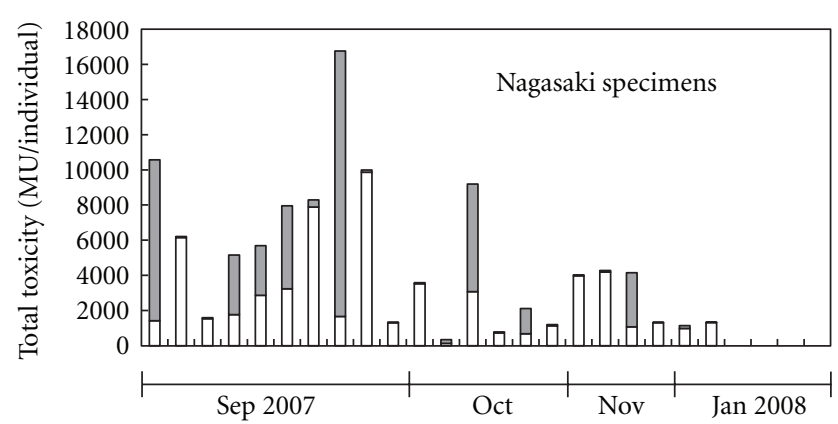

(a)

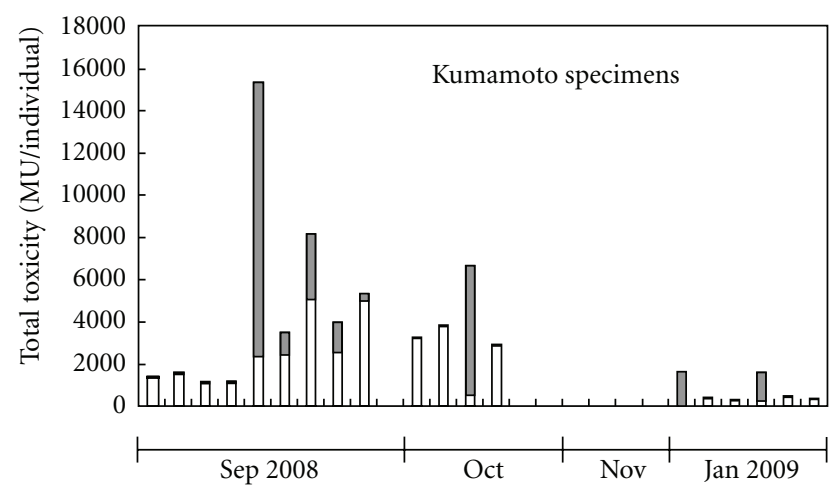

๑ Viscera

口 Muscle

(b)

Figure 4: Toxicity of N. glans collected from Tachibana Bay, Nagasaki Prefectuire (a) and Miyanokawachi Bay, Kumamoto Prefecture (b).

effect of TTX, we observed a significantly positive correlation between toxicity and comparative attracting variations in toxic species, whereas nontoxic species showed a negative response to TTX [39]. Carnivorous or necrophagous marine snails generally live at the sea bottom, and their habitat, including their prey and food sources, is very limited. Under such conditions, the snails may be endowed with the ability to detect TTX-bearing foods and to ingest them selectively as a species-specific characteristic.

Although necrophagous small snails ingest TTX-containing foods selectively, they also have access to a diet contaminated with paralytic shellfish poison (PSP; i.e., a group of neurotoxins produced by certain species of dinoflagellates, and the main component, STX, has an almost equivalent molecular size and action mechanism to TTX [40]). In such cases, they accumulate not only TTX but also PSP, as seen in Natica lineate [41], Niotha clathrata [23, 24], and Zeuxis scalaris $[23,24]$ in Pingtung, Taiwan. This is also the case in the toxic crabs Zosimus aeneus in the Philippines [42] and Taiwan [43], and Atergatis floridus in Taiwan [44].

5.4. Sea Slugs. According to McNabb et al., sea slugs are carnivorous scavengers living in the shallow subtidal crustose turf/benthic algal communities [9]. The mechanisms of their TTX intoxication remain uncertain. Sea slugs are generally not used for human food, but the dog poisonings may be viewed as a warning to human public hygiene. Namely, if their intoxication is caused by a route other than the presently known food chain, this may suggest a novel original organism of TTX, and the food chain that begins with this organism may contaminate seafood previously thought to be safe with TTX.

\section{Conclusion}

TTX was originally named after the family name, Tetraodontidae, of pufferfish as their exclusive toxin, and TTX poisoning due to ingestion of pufferfish has long been recognized. TTX poisoning due to gastropods, however, has also begun to occur frequently, posing a serious food hygiene problem. TTX is exogenous to both pufferfish and gastropods, and they are thought to ingest it from toxic food organisms and to accumulate the TTX in specific organs. Interestingly, it is presumed that live pufferfish ingest/accumulate TTX from necrophagous small or medium marine snails, while on the other hand, these snails ingest/accumulate the toxin from dead pufferfish. Thus, it is possible that the TTX produced by bacteria not only transfers to higher organisms through the food chain, but that it also partly circulates between certain organisms (Figure 2).

As described above, the pufferfish L. lunaris, originally inhabiting tropical to subtropical sea areas, now frequently appear in the temperate coastal waters of Japan, and dog poisonings due to sea slugs have suddenly begun to occur in the Southern Hemisphere. Such facts indicate the possibility of further geographic expansion and/or diversification of TTXbearing organisms, or of TTX contamination of seafood caused by a change in the marine environment, such as an increase in the water temperature due to global warming. Careful attention must be paid to this point from the food hygiene perspective for the future.

\section{References}

[1] M. Yotsu-Yamashita, "Chemistry of puffer fish toxin," Journal of Toxicology-Toxin Reviews, vol. 20, no. 1, pp. 51-66, 2001.

[2] T. Narahashi, "Pharmacology of tetrodotoxin," Journal of Toxicology-Toxin Reviews, vol. 20, no. 1, pp. 67-84, 2001.

[3] D. F. Hwang and T. Noguchi, "Tetrodotoxin poisoning," Advances in Food and Nutrition Research, vol. 52, pp. 141-236, 2007.

[4] H. S. Mosher, F. A. Fuhrman, H. D. Buchwald, and H. G. Fischer, "Tarichatoxin-tetrodotoxin: a potent neurotoxin," Science, vol. 144, no. 3622, pp. 1100-1110, 1964.

[5] K. Miyazawa and T. Noguchi, "Distribution and origin of tetrodotoxin," Journal of Toxicology-Toxin Reviews, vol. 20, no. 1, pp. 11-33, 2001.

[6] T. Noguchi and O. Arakawa, "Tetrodotoxin-distribution and accumulation in aquatic organisms, and cases of human intoxication," Marine Drugs, vol. 6, no. 2, pp. 220-242, 2008.

[7] T. Noguchi, O. Arakawa, and T. Takatani, "TTX accumulation in pufferfish," Comparative Biochemistry and Physiology Part D, vol. 1, no. 1, pp. 145-152, 2006.

[8] P. Rodriguez, A. Alfonso, C. Vale et al., "First toxicity report of tetrodotoxin and 5,6,11-trideoxyTTX in the trumpet shell 
Charonia lampas lampas in Europe," Analytical Chemistry, vol. 80, no. 14, pp. 5622-5629, 2008.

[9] P. McNabb, A. I. Selwood, R. Munday et al., "Detection of tetrodotxin from the grey side-gilled sea slug Pleurobranchaea maculate, and associated dog neurotoxicosis on beaches adjacent to the Hauraki Gulf, Auckland, New Zealand," Toxicon, vol. 56, pp. 466-473, 2010.

[10] O. Arakawa, D. F. Hwang, S. Taniyama, and T. Takatani, “Toxins of pufferfish that cause human intoxications," in Coastal Environmental and Ecosystem Issues of the East China Sea, A. Ishimatsu and H.-J. Lie, Eds., pp. 227-244, Nagasaki University/TERRAPUB, Tokyo, Japan, 2010.

[11] L. Ngy, S. Taniyama, K. Shibano, C. F. Yu, T. Takatani, and O. Arakawa, "Distribution of tetrodotoxin in pufferfish collected from coastal waters of Sihanouk Ville, Cambodia," Journal of the Food Hygienic Society of Japan, vol. 49, no. 5, pp. 361-365, 2008.

[12] H. Narita, T. Noguchi, J. Maruyama et al., "Occurrence of tetrodotoxin in a trumpet shell, "boshubora"” Bulletin of the Japanese Society for the Science of Fish, vol. 47, pp. 935-941, 1981.

[13] T. Noguchi, J. Maruyama, H. Narita, and K. Hashimoto, "Occurrence of tetrodotoxin in the gastropod mollusk Tutufa lissostoma (frog shell)," Toxicon, vol. 22, no. 2, pp. 219-226, 1984.

[14] S. Machida, "Food poisoning due to ingestion of "ivory shell" Babylonia japonica," Journal of the Food Hygienic Society of Japan, vol. 6, pp. 87-89, 1965.

[15] T. Noguchi, J. Maruyama, Y. Ueda, K. Hashimoto, and T. Harada, "Occurrence of tetrodotoxin in the Japanese ivory shell Babylonia japonica," Bulletin of the Japanese Society for the Science of Fish, vol. 47, pp. 901-913, 1981.

[16] P. A. Hwang, Y. H. Tsai, J. F. Deng, C. A. Cheng, P. H. Ho, and D. F. Hwang, "Identification of tetrodotoxin in a marine gastropod (Nassarius glans) responsible for human morbidity and mortality in Taiwan," Journal of Food Protection, vol. 68, no. 8, pp. 1696-1701, 2005.

[17] H. L. Yin, H. S. Lin, C. C. Huang, D. F. Hwang, J. S. Liu, and W. H. Chen, "Tetrodotoxication with Nassauris glans: a possibility of tetrodotoxin spreading in marine products near Pratas Island," American Journal of Tropical Medicine and Hygiene, vol. 73, no. 5, pp. 985-990, 2005.

[18] S. Taniyama, Y. Isami, T. Matsumoto, Y. Nagashima, T. Takatani, and O. Arakawa, "Toxicity and toxin profile of tetrodotoxin detected in the scavenging gastropod nassarius (Alectrion) glans "kinshibai"', Journal of the Food Hygienic Society of Japan, vol. 50, no. 1, pp. 22-28, 2009.

[19] H. Narita, T. Noguchi, J. Maruyama, and K. Hashimoto, "Occurrence of a tetrodotoxin-associated substance in a gastropod, "hanamushirogai" Zeuxis siquijorensis," Bulletin of the Japanese Society for the Science of Fish, vol. 50, pp. 85-88, 1984.

[20] J. K. Jeon, H. Narita, M. Nara, T. Noguchi, J. Maruyama, and K. Hashimoto, "Occurrence of tetrodotoxin in a gastropod mollusk, "araregai" Niotha clathrata," Bulletin of the Japanese Society for the Science of Fish, vol. 50, pp. 2099-2102, 1984.

[21] L. Shui, K. Chen, J. Y. Wang et al., "Tetrodotoxin-associated snail poisoning in Zhoushan: a 25-year retrospective analysis," Journal of Food Protection, vol. 66, no. 1, pp. 110-114, 2003.

[22] T. Takatani, O. Arakawa, and T. Noguchi, "Food poisonings frequently occurred in China due to small gastropods," Journal of the Food Hygienic Society of Japan, vol. 46, pp. 2008-2009, 2005.
[23] P. A. Hwang, Y. H. Tsai, S. J. Lin, and D. F. Hwang, "The gastropods possessing TTX and/or PSP,” Food Reviews International, vol. 23, no. 4, pp. 321-340, 2007.

[24] D. F. Hwang, C. A. Cheng, H. T. Tsai et al., "Identification of tetrodotoxin and paralytic shellfish toxins in marine gastropod implicated in food poisoning," Fisheries Science, vol. 61, pp. 675-679, 1995.

[25] D. F. Hwang, Y. C. Shiu, P. A. Hwang, and Y. H. Lu, "Tetrodotoxin in gastropods (snails) implicated in food poisoning in Northern Taiwan," Journal of Food Protection, vol. 65, no. 8, pp. 1341-1344, 2002.

[26] K. Ikeda, Y. Murakami, Y. Emoto et al., "Transfer profile of intramuscularly administered tetrodotoxin to non-toxic cultured specimens of the pufferfish Takifugu rubripes," Toxicon, vol. 53, no. 1, pp. 99-103, 2009.

[27] Y. Nagashima, M. Toyoda, M. Hasobe, K. Shimakura, and K. Shiomi, "In vitro accumulation of tetrodotoxin in pufferfish liver tissue slices," Toxicon, vol. 41, no. 5, pp. 569-574, 2003.

[28] T. Matsumoto, Y. Nagashima, K. Takayama, K. Shimakura, and K. Shiomi, "Difference between tetrodotoxin and saxitoxins in accumulation in puffer fish Takifugu rubripes liver tissue slices," Fish Physiology and Biochemistry, vol. 31, no. 1, pp. 95100, 2005.

[29] T. Matsumoto, Y. Nagashima, H. Kusuhara et al., "Involvement of carrier-mediated transport system in uptake of tetrodotoxin into liver tissue slices of puffer fish Takifugu rubripes," Toxicon, vol. 50, no. 2, pp. 173-179, 2007.

[30] T. Matsumoto, Y. Nagashima, H. Kusuhara, S. Ishizaki, K. Shimakura, and K. Shiomi, "Pharmacokinetics of tetrodotoxin in puffer fish Takifugu rubripes by a single administration technique," Toxicon, vol. 51, no. 6, pp. 1051-1059, 2008.

[31] T. Matsumoto, Y. Nagashima, H. Kusuhara, S. Ishizaki, K. Shimakura, and K. Shiomi, "Evaluation of hepatic uptake clearance of tetrodotoxin in the puffer fish Takifugu rubripes," Toxicon, vol. 52, no. 2, pp. 369-374, 2008.

[32] T. Matsui, K. Yamamori, K. Furukawa, and M. Kono, "Purification and some properties of a tetrodotoxin binding protein from the blood plasma of kusafugu, Takifugu niphobles," Toxicon, vol. 38, no. 3, pp. 463-468, 2000.

[33] M. Yotsu-Yamashita, A. Sugimoto, T. Terakawa, Y. Shoji, T. Miyazawa, and T. Yasumoto, "Purification, characterization, and cDNA cloning of a novel soluble saxitoxin and tetrodotoxin binding protein from plasma of the puffer fish, Fugu pardalis," European Journal of Biochemistry, vol. 268, no. 22, pp. 5937-5946, 2001.

[34] K. Ikeda, Y. Emoto, R. Tatsuno et al., "Maturation-associated changes in toxicity of the pufferfish Takifugu poecilonotus," Toxicon, vol. 55, no. 2-3, pp. 289-297, 2010.

[35] T. Noguchi, H. Narita, J. Maruyama, and K. Hashimoto, "Tetrodotoxin in the starfish Astropecten polyacanthus, in association with toxification of a trumpet shell, "Boshubora", Charonia sauliae," Bulletin of the Japanese Society for the Science of Fish, vol. 48, pp. 1173-1177, 1982.

[36] J. Maruyama, T. Noguchi, H. Narita, J. K. Jeon, M. Otsuka, and K. Hashimoto, "Occurrence of tetrodotoxin in a starfish, Astropecten scoparius," Agricultural and Biological Chemistry, vol. 49, pp. 3069-3070, 1985.

[37] J. Maruyama, T. Noguchi, and K. Jeon, "Occurrence of tetrodotoxin in the starfish Astropecten latespinosus," Experientia, vol. 40, no. 12, pp. 1395-1396, 1984.

[38] H. Narita, "Distribution of tetrodotoxin in mollusks and echidermis," in Recent Advances in Tetrodotoxin Research, K. Hashimoto, Ed., pp. 45-52, JSFS, Tokyo, Japan, 1988. 
[39] P. A. Hwang, T. Noguchi, and D. F. Hwang, "Neurotoxin tetrodotoxin as attractant for toxic snails," Fisheries Science, vol. 70, no. 6, pp. 1106-1112, 2004.

[40] J. R. Deeds, J. H. Landsberg, S. M. Etheridge, G. C. Pitcher, and S. W. Longan, "Non-traditional vectors for paralytic shellfish poisoning," Marine Drugs, vol. 6, no. 2, pp. 308-348, 2008.

[41] D. F. Hwang, C. H. Chueh, and S. S. Jeng, "Occurence of tetrodotoxin in the gastropod mollusk Natica lineata (lined moon shell)," Toxicon, vol. 28, no. 1, pp. 21-27, 1990.

[42] O. Arakawa, Studies on paralytic toxins in crabs of the family Xanthidae, Ph.D. thesis, University of Tokyo, 1988.

[43] Y. H. Tsai, D. F. Hwang, T. J. Chai, and S. S. Jeng, "Toxicity and toxic components of two xanthid crabs, Atergatis floridus and Demania reynaudi, in Taiwan," Toxicon, vol. 35, no. 8, pp. 1327-1335, 1997.

[44] Y. H. Tsai, S. S. Jeng, and D. F. Hwang, "Seasonal and regional variations of toxicity in the xanthid crab Zosimus aeneus in Taiwan," Fisheries Science, vol. 63, no. 2, pp. 313-314, 1997. 

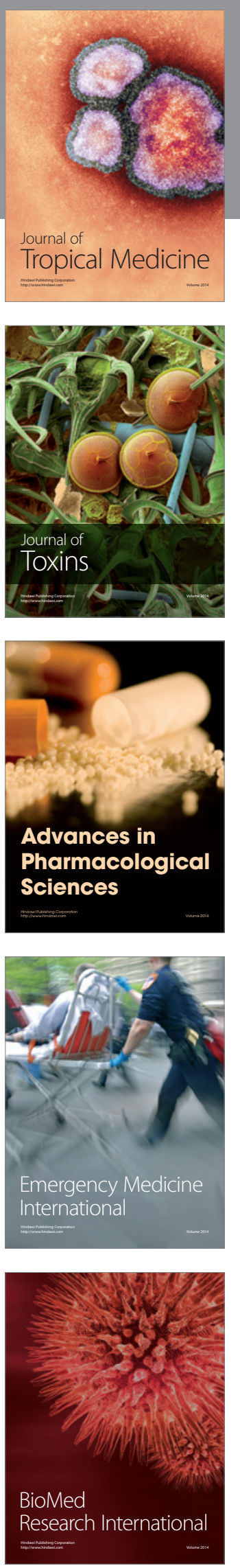
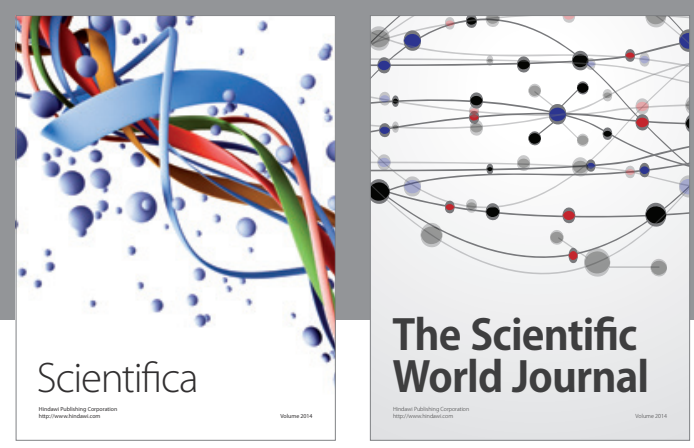

The Scientific World Journal
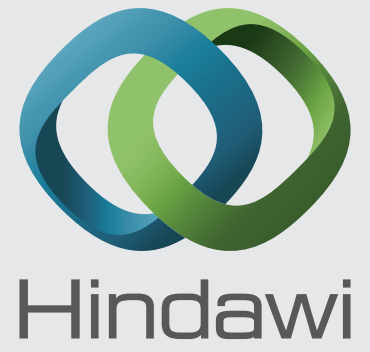

Submit your manuscripts at

http://www.hindawi.com
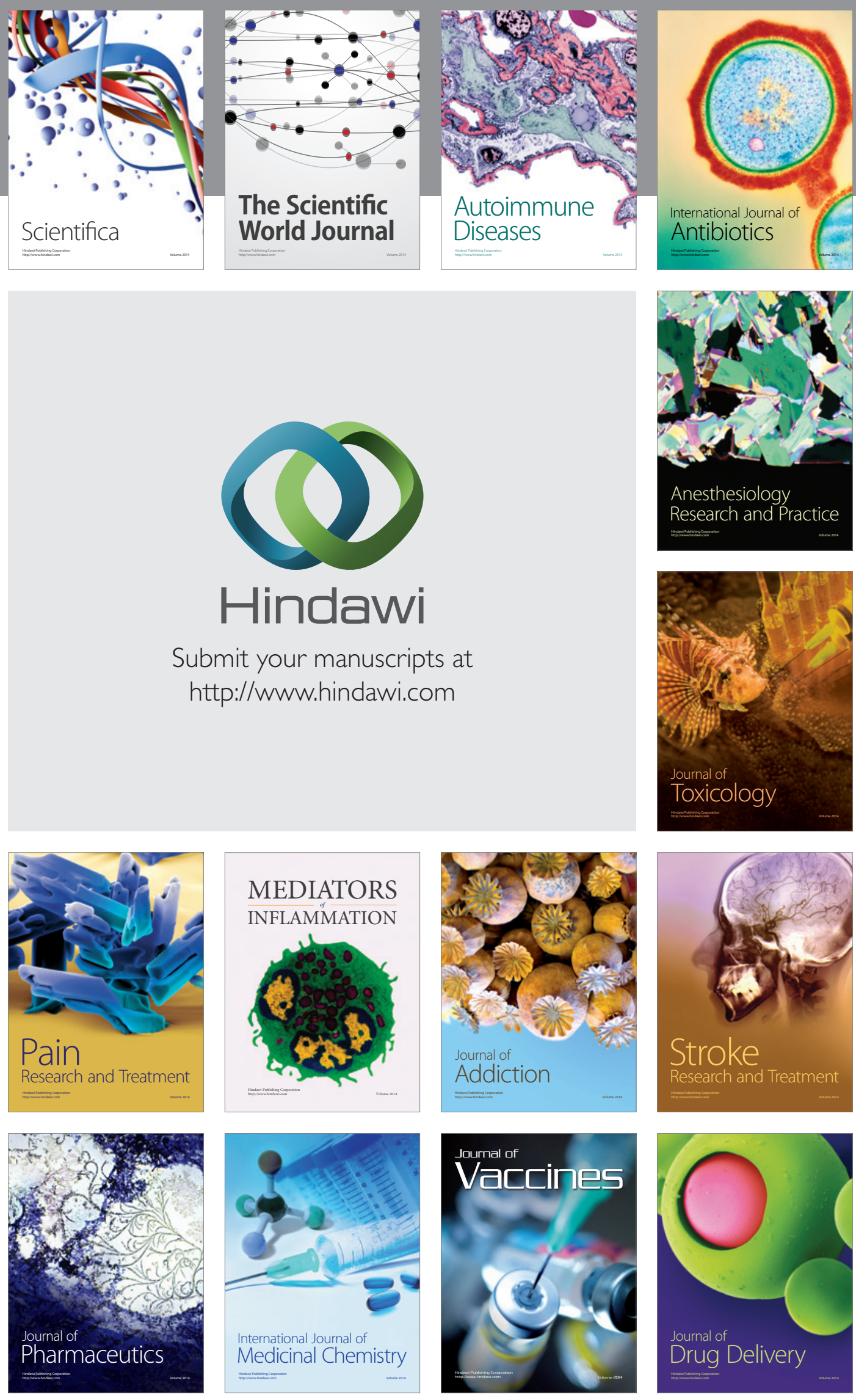